\title{
Struktur Pendapatan Rumah Tangga dan Tingkat Kesejahteraan Petani Di Kecamatan Muara Sabak Timur Kabupaten Tanjung Jabung Timur
}

\author{
Evi Adriani ${ }^{1 *}$, Susilawati ${ }^{2}$, Ali Fahmi ${ }^{3}$ \\ ${ }^{1,2}$ Fakultas Ekonomi Universitas Batanghari \\ ${ }^{3}$ Universitas Muhammadiyah Jambi \\ *correspondence email: adrianievifahlevi@gmail.com
}

\begin{abstract}
Abstrak. Penelitian ini bertujuan untuk menganalisis struktur pendapatan rumah tangga dan tingkat kesejahteraan petani subsektor tanaman pangan dan hortikultura di Kecamatan Muara Sabak Timur. Metode survei dengan menggunakan kuesioner dilakukan untuk mengumpulkan data primer sebagai data utama dalam penelitian ini. Metode sampling yang digunakan adalah purpossive sampling untuk menentukan sampel lokasi dan accidental sampling digunakan untuk menentukan responden petani sebanyak 40 petani secara langsung di lokasi. Metode analisis data dengan statistik deskriptif dan regresi logistik. Hasil penelitian menunjukan bahwa sumber pendapatan rumah tangga petani di kecamatan Muara Sabak Timur masih di dominasi oleh pendapatan utama dari usaha tani tanaman pangan dan hortikutura meskipun saat ini hampir semua petani memiliki pekerjaan diluar usahatani sebagai pekerjaan sampingan. Variabel pendapatan dan jumlah anggota keluarga berpengaruh signifikan terhadap kesejahteraan petani dengan arah yang positif sedangkan pendidikan kepala rumah tangga berpengaruh signifikan dengan arah yang negatif.
\end{abstract}

Kata Kunci: struktur pendapatan, kesejahteraan, ketahanan pangan, nilai tukar petani, regresi logistik

\begin{abstract}
This study aims to analyze the structure of household income and the level of welfare of farmers in the sub-sector of food crops and horticulture in Muara Sabak Timur Subdistrict. The survey method using questionnaires was conducted to collect primary data as the main data in this study. The sampling method used is purpossive sampling to determine the sample location and accidental sampling is used to determine the respondents of farmers as many as 40 farmers directly at the site. Data analysis method with descriptive statistics and logistic regression. The results showed that the source of income of farmers' households in Muara Sabak Timur subdistrict is still dominated by the main income from food crops and hortikutura farming even though today almost all farmers have jobs outside the farm as a side job. Variable income and the number of family members have a significant impact on the welfare of farmers in a positive direction while the education of the head of the household has a significant effect with a negative direction.
\end{abstract}

Keywords: income structure, welfare, food security, farmer exchange rate, logistic regression

\section{Pendahuluan}

Pembangunan pertanian terutama berorientasi ke arah perbaikan kesejahteraan pelaku pembangunan, khususnya petani yang bergerak di bidang budidaya tanaman pangan dan tanaman hortikultura. Secara khusus kesejahteraan petani pangan perlu menjadi perhatian, karena berkaitan dengan masa depan usaha tani padi atau pangan lainnya dalam kesinambungan produksi sebagai makanan pokok masyarakat Indonesia. Dalam peningkatan kesejahteraan petani perlu adanya tolak ukur sebagai indikator apakah terjadi perbaikan pada tingkat kesejahteraan petani (Keumala \& Zainuddin, 2018). Beberapa indikator yang dapat digunakan untuk mengetahui tingkat kesejahteraan petani antara lain; pendapatan rumah tangga, pengeluaran rumah tangga, ketahanan pangan rumah tangga dan nilai tukar petani. Pendapatan sebagai salah satu indikator kesejahteraan seringkali dijadikan sebagai sasaran akhir pembangunan termasuk pembangunan pada sektor pertanian. Pendapatan petani merupakan ukuran penghasilan yang diterima oleh petani dari usahataninya. Pendapatan total rumahtangga pertanian merupakan penjumlahan dari seluruh nilai hasil produksi komoditas pertanian yang dihasilkan petani, nilai dari berburuh tani, nilai hasil produksi usaha non-pertanian, nilai dari berburuh non pertanian, dan lainnya (kiriman dan lain- lain). Sedangkan pengeluaran petani merupakan penjumlahan dari pengeluaran untuk konsumsi rumahtangga dan pengeluaran untuk biaya produksi.

Sumber pendapatan rumah tangga petani dikelompokkan ke dalam tiga sumber, yaitu: (1) pendapatan yang berasal dari kegiatan usahatani (on farm), (2) pendapatan dari kegiatan pertanian di luar usahatani (off-farm), dan (3) pendapatan dari kegiatan di luar pertanian (non-farm) (Burhansyah \& Pribadi, 2016); (Elizabeth \& Darwis, 2000). Faktor penarik yang berasal dari luar petani berkaitan dengan makin terbukanya peluang pekerjaan di luar sektor pertanian yang dirasa lebih nyaman dan lebih menjanjikan. Studi yang dilakukan Wahyuni (2013) dan Mariyati (2015) untuk melihat struktur pendapatan petani dibagi menjadi dua kelompok yaitu pendapatan pertanian dan pendapatan non pertanian. Pendapatan pertanian berupa pendapatan usahatani perkebunan, perikanan, peternakan dan buruh pertanian. Sedangkan pendapatan non pertanian berupa perdagangan dan jasa. Hasil studi menunjukkan bahwa pendapatan terbesar petani berasal dari pendapatan pertanian khususnya dari usahatani perkebunan. Struktur 
pendapatan adalah komponen penyusun pendapatan baik itu yang pokok maupun tambahan yang diperoleh seluruh anggota dalam periode waktu tertentu, dapat berupa uang ataupun barang. Berdasarkan jenisnya, sumber pendapatan dapat dibedakan menjadi dua yaitu pendapatan utama dan pendapatan tambahan. Pendapatan utama adalah sumber penghasilan rumahtangga yang paling menunjang kehidupan rumahtangga atau yang memberikan penghasilan terbesar. Pada umumnya mata pencaharian utama memiliki alokasi waktu kerja yang terbesar jika dibandingkan dengan kegiatan lainnya. Sedangkan pendapatan tambahan didefinisikan sebagai penghasilan yang diperoleh rumahtangga dengan mengusahakan kegiatan lain diluar pekerjaan utama (Karolina et al., 2016).

Nilai tukar petani (NTP) menggambarkan tingkat daya tukar/daya beli petani terhadap produk yang dibeli/dibayar petani yang mencakup konsumsi dan input produksi yang dibeli (Riyadh, 2016). Semakin tinggi nilai tukar petani, semakin baik daya beli petani terhadap produk konsumsi dan input produksi tersebut, dan berarti secara relatif lebih sejahtera (Nirmala et al., 2016). Pengeluaran rumah tangga juga merupakan salah satu indikator yang dapat memberikan gambaran keadaan kesejahteraan keluarga melalui struktur pengeluaran rumah tangga tersebut (Rahmadin \& P, 2018). Struktur pengeluaran rumah tangga secara umum berupa kebutuhan untuk pangan dan non pangan, di mana kebutuhan keduanya berbeda. Pengeluaran pangan rumah tangga akan meningkat sejalan dengan meningkatnya pendapatan, tetapi seiring dengan pergeseran dan peningkatan pendapatan, proporsi pola pengeluaran untuk pangan akan menurun dan pengeluaran untuk kebutuhan non pangan akan meningkat (Burhansyah \& Pribadi, 2016). Fenomena ini dikenal sebagai Hukum Engel (Mayasari et al., 2018). Teori Engel ini sangat penting untuk mempelajari tingkat kesejahteraan ekonomi suatu masyarakat. Kesejahteraan dikatakan makin baik apabila persentase pengeluaran untuk makanan semakin kecil dibandingkan dengan total pengeluaran untuk non makanan (Rambe, 2006). Struktur pengeluaran rumah tangga ini menunjukkan tingkat kesejahteraannya, dimana rumah tangga dengan pangsa pengeluaran pangan yang lebih tinggi tergolong rumah tangga dengan tingkat kesejahteraan relatif rendah dan sebaliknya (Mayasari et al., 2018).

Pola konsumsi ialah kebutuhan manusia baik dalam bentuk benda maupun jasa yang dialokasikan selain untuk kepentingan pribadi juga keluarga yang didasarkan pada tata hubungan dan tanggung jawab yang dimiliki yang sifatnya terealisasi sebagai kebutuhan primer dan sekunder. Pola konsumsi juga dapat diartikan sebagai tanggapan aktif manusia terhadap lingkungan alam maupun lingkungan sosial yang berkaitan erat dengan kehidupan kebudayaan masyarakat, dimana tanggapan aktif yang ada bisa dalam bentuk pemenuhan kebutuhan primer dan sekunder (Puspita \& Agustina, 2020). Pola konsumsi rumah tangga tersebut akan menggambarkan kualitas hidup rumah tangga dan menggambarkan tingkat kesejahteraan rumah tangga (Adriani et al., 2020). Angka kemiskinan di Kabupaten Tanjung Jabung Timur (Tanjabtim) selama tiga tahun terakhir telah menunjukkan penurunan, yang semula sebesar 12,58 persen pada tahun 2017 menjadi 11,54 persen tahun 2019 (BPS Provinsi Jambi, 2020). Meskipun telah mengalami penurunan, namun angka kemiskinan di Kabupaten Tanjabtim ini masih merupakan persentase penduduk miskin terbesar dibandingkan kabupaten/kota lainnya di Provinsi Jambi. Lagipula indeks kedalaman dan indeks keparahan kemiskinannya selalu mengalami peningkatan setiap tahunnya. Di sisi lain, kabupaten Tanjabtim merupakan daerah sentra produksi padi di provinsi Jambi. Muara Sabak Timur adalah salah satu kecamatan di kabupatem Tanjabtim yang sebagian besar penduduknya bekerja di sektor pertanian, terutama sub sektor tanaman pangan dan hortikultura. Sejalan dengan fungsi tersebut dan dalam usaha meningkatkan produksi pertanian terutama sub sektor tanaman pangan dan hortikultura, pemerintah daerah telah berupaya melaksanakan beberapa program pembangunan di sektor pertanian agar pendapatan dan kesejahteraan petani menjadi semakin baik. Dalam peningkatan kesejahteraan petani perlu adanya tolok ukur yang dapat dilihat perkembangannya. Oleh karena itu, sangat relevan untuk mengkaji struktur pendapatan dan pengeluaran rumah tangga serta tingkat kesejahteraan petani tanaman pangan dan hortikultura di kecamatan Muara Sabak Timur kabupaten Tanjung Jabung Timur.

Penelitian ini bertujuan untuk: 1) Menganalisis struktur pendapatan dan pengeluaran rumah tangga petani di Kecamatan Muara Sabak Timur; 2) Menganalisis faktor-faktor yang mempengaruhi tingkat kesejahteraan petani di Kecamatan Muara Sabak Timur.

\section{Metode}

Penelitian ini menggunakan data primer yang diperoleh dari petani tanaman pangan dan hortikultura sebagai responden. Metode pengumpulan data yaitu metode survey dan alat pengumpul data yang digunakan adalah kuesioner/angket. Metode kuesioner berbentuk rangkaian atau kumpulan pertanyaan yang disusun secara sistimatis dalam sebuah daftar pertanyaan kemudian dikirim/diberikan kepada responden untuk diisi (Bungin, 2013). Bentuk kuesioner yang digunakan dalam penelitian ini bersifat terbuka dimana responden diberikan kebebasan untuk mengisi atau menjawab pertanyaan sesuai dengan kondisi/pengalaman riil yang dialami responden. Selain dengan kuesioner, penelitian ini juga menggunakan metode wawancara yang bertujuan untuk melengkapi dan memverifikasi data dari kuesioner. Wawancara ini dilakukan kepada penyuluh pertanian lapangan (PPL) yang bertugas di kecamatan lokasi penelitian dan juga kepada responden untuk mendapatkan informasi yang lebih luas dan dalam. 
Lokasi penelitian ditentukan dengan sengaja (purposive sampling), dengan pertimbangan bahwa lokasi tersebut merupakan salah satu dari lima (5) wilayah dengan tingkat produksi/ha (produktivitas) tertinggi dan jumlah masyarakat yang mata pencarian utamanya adalah sub-sektor tanaman pangan dan hortikultura (Dinas Pertanian Tanjabtim, 2019). Jumlah sampel sebanyak 40 responden dilakukan dengan metode Accidental Sampling. Metode analisis data adalah metode deskriptif dan inferensial. Metode statistik deskriptif digunakan untuk menganalisis struktur pendapatan dan pengeluaran rumah tangga petani, sementara statistik inferensial dengan metode regresi logistik digunakan untuk menganalisis faktor-faktor yang mempengaruhi tingkat kesejahteraan rumah rumah tangga petani.

Kesejahteraan petani sebagai variabel terikat dalam penelitian ini diwakili oleh proporsi pengeluaran pangan rumah tangga yang merupakan variabel dikotomi. Variabel independennya adalah faktor-faktor yang dianggap berpengaruh terhadap ketahanan pangan yaitu jumlah pendapatan rumah tangga, jumlah anggota keluarga dan tingkat pendidikan kepala rumah tangga. Karena variabel terikat dalam penelitian ini merupakan variabel dengan dua kategori, maka analisis menggunakan model Binary Logistic. Dengan menggunakan model ini dapat diketahui apakah ada pengaruh antara variabel independent terhadap variabel dependent (Agresti, 2007; Latan, 2014). Persamaan regresi yang sesuai dengan penelitian adalah:

Prob(kesejahteraan) = f (pendapatan, jumlah anggota keluarga, pendidikan) dan model Regresi Logistik dari persamaan tersebut dapat ditulis sebagai berikut:

$\mathrm{Li}=\ln \left[\frac{\mathrm{pi}}{1-\mathrm{pi}}\right]=\beta_{0}+\beta_{1} \mathrm{Inc}+\beta_{2} \mathrm{JAK}+\beta_{3} \mathrm{Edu}+\epsilon$

$\mathrm{W}=\beta_{0}+\beta_{1} \mathrm{Inc}+\beta_{2} \mathrm{JAK}+\beta_{3} \mathrm{Edu}+\epsilon$

Keterangan: $\mathrm{W}=$ variabel dikotomi, kesejahteraan petani (peluang peningkatan proporsi pengeluaran konsumsi pangan rumah tangga petani); $\mathrm{W}=0$ : tidak sejahtera, yaitu proporsi pangan $>60 \%$; $\mathrm{W}=1$ : sejahtera, yaitu proporsi pangan $\leq 60 \%$; Inc = pendapatan total rumahtangga $(\mathrm{Rp} / \mathrm{bln}) ; \mathrm{JAK}=$ Jumlah anggota keluarga (orang); Edu = Pendidikan yang ditamatkan; Edu $=0$, pendidikan KRT $<$ SLTA; Edu $=1$, pendidikan KRT $\geq$ SLTA; $\beta_{0,1,2,3}=$ nilai parameter; $\epsilon=$ galat $/$ residu

\section{Hipotesis Statistik}

1. Ho: $\beta 1=0$; Pendapatan total rumahtangga tidak berpengaruh terhadap peluang peningkatan proporsi pengeluaran konsumsi pangan rumahtangga/ kesejahteraan

Ha: $\beta 1 \neq 0$; Pendapatan total rumahtangga berpengaruh terhadap peluang peningkatan proporsi pengeluaran konsumsi pangan rumahtangga

2. Ho: $\beta 2=0$; Jumlah anggota keluarga rumahtangga tidak berpengaruh terhadap peluang peningkatan proporsi pengeluaran konsumsi pangan rumahtangga

Ha: $\beta 2 \neq 0$; Jumlah anggota keluarga rumahtangga berpengaruh terhadap peluang peningkatan proporsi pengeluaran konsumsi pangan rumahtangga

3. Ho: $\beta 3=0$; Tidak ada perbedaan peluang peningkatan proporsi pengeluaran konsumsi pangan rumahtangga berdasarkan tingkat pendidikan kepala rumahtangga

Ha: $\beta 3 \neq 0$; Ada perbedaan peluang peningkatan proporsi pengeluaran konsumsi pangan rumahtangga berdasarkan tingkat pendidikan kepala rumahtangga

Tahapan yang dilakukan dalam analisis regresi logistik adalah sebagai berikut:

1. Melakukan uji independensi untuk semua variabel bebas. Uji ini untuk melihat apakah terdapat hubungan yang signifikan antara masing-masing variabel bebas terhadap variabel terikat. Jika tidak terdapat hubungan yang signifikan antara suatu variabel bebas dengan variabel terikat, maka variabel tersebut tidak dimasukkan ke dalam model regresi logistik. Pengujian dilakukan dengan Pearson Chi-square dengan kriteria adalah menolak $\mathrm{H}_{0}$ jika $P$-value lebih kecil dari $\alpha=0,05$, artinya terdapat hubungan yang signifikan antara variabel bebas dengan variabel terikat (Agresti, 2007).

2. Uji Kelayakan Model (Goodness of Fit test), bertujuan untuk mengetahui kelayakan atau ketepatan model regresi yang dibentuk. Dikatakan tepat apabila tidak ada perbedaan signifikan antara model dengan nilai observasinya. Metode pengujian yang digunakan dalam penelitian ini adalah Hosmer and Lemeshow Test, dengan membandingkan nilai probabilitas ( $p$-value) dengan nilai tingkat keyakinan $(\alpha)$. Model yang layak menurut uji statistik ini akan mempunyai nilai probabilitas ( $p$-value) yang besar, yaitu lebih besar dari tingkat keyakinan $\alpha=$ 0.05 .

3. Uji signifikansi parsial koefisien regresi.

Uji signifikansi secara parsial dengan memperhatikan probabilitas hasil perhitungan uji Wald. Pada uji ini diharapkan $\mathrm{H}_{0}$ ditolak sehingga variabel yang sedang diuji masuk ke dalam model. Kriteria yang digunakan adalah jika sig. kecil dari a, maka $\mathrm{H}_{0}$ ditolak. 
4. Estimasi dan interpretasi parameter persamaan regresi, yaitu: membuat persamaan regresi logistiknya lewat penghitungan koefisien persamaan. Untuk menginterpretasikannya, koefisien hasil estimasi logit tersebut ditransformasikan dulu ke dalam antilogaritma natural sehingga didapatkan nilai Odds Ratio. Odds Ratio merupakan rasio antara dua peluang yaitu sukses dan gagal. Peluang sukses pada penelitian ini diartikan sebagai peluang/kecenderungan rumahtangga petani menjadi sejahtera (tahan pangan) dan peluang gagal diartikan sebagai peluang rumah tangga menjadi tidak sejahtera (rawan pangan).

\section{Definisi Operasional Variabel.}

1. Penerimaan petani adalah total hasil produksi pertanian tanaman pangan dan hortikultura (Rp/bln).

2. Pendapatan utama adalah pendapatan petani dari pertanian tanaman pangan dan hortikultura, yang merupakan selisih penerimaan dengan total biaya produksi pertanian tanaman pangan dan hortikultura $(\mathrm{Rp} / \mathrm{bln})$.

3. Pendapatan sampingan adalah pendapatan rumah tangga tani yang diterima selain dari kegiatan pertanian tanaman pangan dan hortikultura seperti perkebunan, dagang, peternakan dan perikanan, jasa dan lain-lain (Rp/bln).

4. Pendapatan total adalah jumlah pendapatan utama dan sampingan (Rp/bln).

5. Tingkat kesejahteraan petani adalah proporsi pengeluaran pangan rumahtangga petani. Jika $\leq 60 \%$, dikategorikan sejahtera dan jika $>60 \%$, dikategorikan tidak sejahtera.

\section{Hasil \\ Struktur Pendapatan Rumah Tangga Petani}

Pendapatan petani dalam penelitian ini dikelompokkan menjadi dua yaitu pendapatan utama dan pendapatan sampingan. Pendapatan utama adalah penerimaan dari usaha tani tanaman pangan dan hortikutura dikurang dengan total biaya produksi pertanian sedangkan pendapatan sampingan adalah penerimaan yang bersumber dari luar usaha tani tanaman pangan dan hortikutura. Struktur pendapatan rumah tangga petani pada umumnya dibagi menjadi dua yaitu bersumber dari pendapatan di sektor pertanian dan non pertanian. Hampir semua responden menanam jenis tanaman pangan (95\%), dimana jenis tanaman pangan dan hortikultura yang ditanam oleh petani respoden di Kecamatan Muara Sabak Timur cukup beragam. Selain padi terdapat juga jagung dan kacang-kacangan (kedele dan kacang tanah) dan untuk hortikultura yang terdiri dari sayuran dan buah-buahan jenis tanamannya adalah cabe, mentimun, kacang panjang, sawi, terong, kangkung, dan buah-buahannya adalah buah naga dan lengkeng.

Sumber pendapatan yang berasal dari luar usaha pertanian yaitu dari petani tanaman pangan dan hortikultura di Kecamatan Muara Sabak Timur berdasarkan data sampel hampir seluruhnya (95\%) memiliki perkerjaan sampingan. Sebagian besar $(65 \%)$ pekerjaan sampingannya adalah campuran. Hal ini terutama dikarenakan mereka menyadari sepenuhnya bahwa jika hanya mengandalkan pendapatan dari perkerjaan utama seperti petani padi. pendapatannya sangatlah tidak mencukupi untuk pemenuhan kebutuhannya. Pekerjaan campuran dimaksud adalah mereka bekerja sebagai petani padi dan juga sebagai buruh. menangkap ikan. dagang dan pekerjaan lainnya. Artinya tergantung pada peluang pekerjaan yang tersedia untuk menambah pendapatan mereka. Namun disisi lain ternyata masih ada sekitar 5\% mereka yang tidak memiliki perkerjaan sampingan atau pekerjaan lain selain dari pekerjaan utama sebagai petani tanaman pangan dan hortikultura. Tabel 1 berikut menjelaskan struktur pendapatan berdasarkan sumber pendapatan rumah tangga.

Pendapatan utama yang bersumber dari usaha tani tanaman pangan dan hortikultura rata-rata sebesar Rp 3.483.470, yang terbesar bersumber dari padi yaitu sebesar 76,90\%, sementara jenis tanaman hortikultura justru negatif kontribusinya terhadap pendapatan rumahtangga $(-0,71 \%)$. Artinya biaya produksi tanaman hortikultura jauh lebih besar dibandingkan penerimaan tani, sehingga pendapatannya negatif. Hal ini dipengaruhi oleh harga produk hortikultura yang sangat rendah di pasar dan juga lahan yang digunakan sangat sempit dibandingkan padi dan jagung. Namun demikian, jika dilihat dari sumbangan pendapatan usaha tani tanaman pangan dan hortikultura secara total terhadap pendapatan total rumahtangga petani sebesar $60,62 \%$, hal ini menunjukkan bahwa usaha tani tanaman pangan dan hortikultura masih merupakan sumber pendapatan utama bagi masyarakat meskipun saat ini petani memiliki pekerjaan diluar usahatani (pekerjaan sampingan). Kontribusi pendapatan dari usaha tani tanaman pangan dan hortikultura sebagai pendapatan utama yang lebih dari $60 \%$ ini relevan dengan rata-rata kontribusi pendapatan dari berbagai hasil penelitian yang berkisar antara 65 persen hingga 50 persen dan pendapatan diluar sektor pertanian antara 35 persen hingga 50 persen (Rusastra, 1998; Adyana et al., 1999; Nurmanaf et al., 2005; Muchjidin et al., 1997; Kasryno, 2000).

Jenis pekerjaan sampingan (di luar usaha tani tanaman pangan dan hortikultura) yang diusahakan petani cukup beragam yaitu perkebunan, peternakan, perikanan, buruh, perdagangan, jasa dan lainnya. Pendapatan rata-rata dari pekerjaan sampingan adalah sebesar Rp 2.263.167, sehingga menambah pendapatan total menjadi sebesar $\mathrm{Rp}$ 5.746.637. Sumbangan terbesar terhadap pendapatan rumahtangga dari pekerjaan sampingan ini masih bersumber dari sektor pertanian (kebun, ternak, perikanan) yang menyumbang lebih dari 70\% dari total pendapatan sampingan. Jika dibandingkan pendapatan rerata $(\mathrm{Rp} / \mathrm{bln} / \mathrm{KK})$ yang diterima petani dari pendapatan utamanya dengan tingkat upah 
minimum kabupaten (UMK)yaitu sebesar Rp.2.630.162 maka dapat dinyatakan bahwa rumah tangga petani sudah sejahtera. Apalagi jika dibandingkan dengan rerata $(\mathrm{Rp} / \mathrm{bln} / \mathrm{KK})$ pendapatan totalnya yang jumlahnya rerata lebih dua kali lipat dari UMK.

Tabel 1

Struktur Pendapatan Berdasarkan Sumber Pendapatan Rumahtangga Petani

\begin{tabular}{|clrc|}
\hline & Sumber Pendapatan & Rerata (Rp/bln/KK) & Persentase \\
& Pendapatan Utama & $\mathbf{3 . 4 8 3 . 4 7 0}$ & $\mathbf{6 0 , 6 2}$ \\
& a. Padi & 2.678 .932 & 76,90 \\
b. Jagung & 765.259 & 21,97 \\
c. Ubi & 64.000 & 1,84 \\
& d. Hortikultura & -24.721 & $-0,71$ \\
2. Pendapatan Sampingan & $\mathbf{2 . 2 6 3 . 1 6 7}$ & $\mathbf{3 9 , 3 8}$ \\
a. Kebun (sawit, karet) & 1.437 .333 & 63,51 \\
b. Perikanan & 25.000 & 1,10 \\
c. Petemakan & 179.583 & 7,94 \\
d. Dagang & 182.500 & 8,06 \\
e. Buruh & 132.500 & 5,85 \\
f. Lainnya & 306.250 & 13,53 \\
Total Pendapatan & $\mathbf{5 . 7 4 6 . 6 3 7}$ & 100,00 \\
\hline
\end{tabular}

Sumber: Data diolah

Tabel 2

Distribusi Pendapatan Rumahtangga Petani

\begin{tabular}{lrrr}
\hline & Pendapatan Utama & Pendapatan Sampingan & Pendapatan Total \\
\hline Terendah & -988.834 & 0 & -988.834 \\
Tertinggi & 16.959 .375 & 8.500 .000 & 20.790 .861 \\
Rerata & 3.483 .470 & 2.263 .167 & 5.746 .637 \\
< Rerata (\%) & 67,5 & 72,5 & 57,5 \\
> Rerata (\%) & 32,5 & 27,5 & 42,5 \\
\hline
\end{tabular}

Sumber: Data diolah

Tabel 2 menunjukkan bahwa distribusi pendapatan diantara petani sangatlah tidak merata yang terlihat dari sangat timpangnya jarak antara jumlah pendapatan terendah yang diterima petani dengan pendapatan tertinggi. Ratarata total pendapatan rumah tangga yang terendah sebesar $\mathrm{Rp}-988.834$, sementara yang tertinggi adalah $\mathrm{Rp}$ 20.790.861. Dengan meningkatnya pendapatan total rumahtangga karena adanya pekerjaan sampingan ini, menyebabkan berkurangnya jumlah petani yang pendapatannya dibawah rerata, dari $67,5 \%$ menjadi $57,5 \%$ atau berkurang sebesar $10 \%$. Dengan kata lain, pekerjaan sampingan mampu meningkatkan kesejahteraan petani secara umum.

\section{Faktor-Faktor Yang Mempengaruhi Tingkat Kesejahteraan Petani}

Untuk menganalis faktor-faktor yang mempengaruhi tingkat kesejahteraan petani dalam penelitian ini digunakan alat analisis regresi logistik. Tahap awal yang dilakukan dalam analisis adalah melakukan uji kelayakan model (Goodness of Fit test), bertujuan untuk mengetahui kelayakan atau ketepatan model regresi yang dibentuk. Dikatakan tepat apabila tidak ada perbedaan signifikan antara model dengan nilai observasinya. Metode pengujian yang digunakan dalam penelitian ini adalah Hosmer and Lemeshow Test, dengan membandingkan nilai probabilitas ( $p$-value) dengan nilai tingkat keyakinan $(\alpha)$. Model yang layak menurut uji statistik ini akan mempunyai nilai probabilitas ( $p$-value) yang besar, yaitu lebih besar dari tingkat keyakinan $\alpha=0.05$. Berdasarkan output SPSS untuk model regresi logistik sebagaimana terdapat pada tabel 3, diperoleh nilai Hosmer and Lemeshow Test sebesar 0,730 lebih besar dari pada alpha 5\% sehingga menerima hipotesis nol (secara statistik tidak terdapat perbedaan yang signifikan antara model dengan nilai observasi) sehingga model dikatakan sudah fit dengan data sehingga layak digunakan. Dengan kata lain model ini dapat digunakan untuk mengetahui pengaruh variabel bebas yaitu pendapatan, jumlah anggota keluarga dan tingkat pendidikan terhadap kesejahteraan petani variabel terikatnya.

Sebelum persamaan regresi logistik diestimasi dan diinterpretasikan, terlebih dahulu dilakukan uji signifikansi setiap variabel bebas secara parsial dengan memperhatikan probabilitas hasil perhitungan uji Wald. Pada uji ini diharapkan $\mathrm{H}_{0}$ ditolak sehingga variabel yang sedang diuji masuk ke dalam model. Kriteria yang digunakan adalah jika sig. kecil dari a, maka $\mathrm{H}_{0}$ ditolak. Pada tabel 3 dapat dilihat bahwa semua variabel bebas memiliki nilai sig. yang lebih kecil dari nilai a (5\%), dengan demikian semua variabel dalam penelitian ini masuk ke dalam model. Terakhir baru dilakukan estimasi dan interpretasi parameter persamaan regresi, yaitu: membuat persamaan regresi logistiknya 
lewat penghitungan koefisien persamaan. Untuk menginterpretasikannya, koefisien hasil estimasi logit tersebut ditransformasikan dulu ke dalam antilogaritma natural sehingga didapatkan nilai Odds Ratio. Odds Ratio merupakan rasio antara dua peluang yaitu sukses dan gagal. Peluang sukses pada penelitian ini diartikan sebagai peluang/kecenderungan rumahtangga petani menjadi sejahtera dan peluang gagal diartikan sebagai peluang rumah tangga menjadi tidak sejahtera.

Tabel 3

Hasil Estimasi Model Regresi Logistik Tingkat Kesejahteraan Petani Tanaman Pangan dan Hortikultura di Kecamatan Muara Sabak Timur

\begin{tabular}{lrrrrr}
\hline Variabel & B & Wald & df & \multicolumn{1}{c}{ Sig. } & Odd Ratio Exp(B) \\
\hline Pendapatan (Inc) &, 001 & 4,037 & 1 & 0,047 & 1,000 \\
Jumlah Anggota Keluarga (JAK) &, 077 & 5,041 & 1 & 0,017 & 1,080 \\
Tingkat Pendidikan (Edu) &,- 140 & 5,022 & 1 & 0,023 &, 869 \\
Konstanta & 1,248 &, 642 & 1 &, 423 & 3,485 \\
Hosmer and Lemeshow Test & & & &, 730 & \\
\hline
\end{tabular}

Sumber: Data diolah

Sesuai informasi pada tabel 3 maka dapat dibuat persamaan model regresi logistik sebagai berikut: $\operatorname{Ln}(\mathrm{p} / 1-\mathrm{p})=1,248+0,001 \mathrm{Inc}+0,077 \mathrm{JAK}-0,140 \mathrm{Edu}$

Berdasarkan hasil uji hipotesis, nilai koefisien regresi logistik dan odd ratio, maka dapat dijelaskan kemaknaan dari masing-masing variabel bebas (Inc, JAK dan Edu) terhadap variabel terikat (W). Variabel pendapatan dan jumlah anggota keluarga berpengaruh signifikan terhadap kesejahteraan petani dan ke duanya memiliki tanda koefisen yang positif. Nilai koefisien yang bertanda positif ini menunjukkan hubungan searah antara variabel pendapatan dan jumlah anggota keluarga dengan variabel tingkat kesejahteraan petani. Artinya semakin besar pendapatan dan jumlah anggota keluarga maka peluang petani untuk mengalokasikan pendapatannya untuk non pangan semakin besar pula, atau dengan kata lain petani semakin sejahtera. Karena variabel pendapatan dan jumlah anggota keluarga merupakan variabel kuantitatif, maka interpretasi dari besaran koefisien tidak dilakukan, kita hanya menganalisi tanda koefisiennya.

Variabel tingkat pendidikan (Edu) juga signifikan pengaruhnya secara statistik terhadap tingkat kesejahteraan petani, tetapi koefisiennya memiliki tanda negatif. Variabel pendidikan dalam penelitian ini merupakan variabel kualitatif (kategori) dengan nilai odd-ratio sebesar 0,869 , berarti rumah tangga yang pendidikan kepala rumah tangganya $\geq$ SLTA menurunkan peluang mereka untuk mengalokasikan pendapatannya untuk non pangan sebesar 0,869 kali dibandingkan yang berpendidikan < SLTA.

\section{Simpulan}

1. Sumber pendapatan rumah tangga petani di kecamatan Muara Sabak Timur masih di dominasi oleh pendapatan utama dari usaha tani tanaman pangan dan hortikutura dengan kontribusi sebesar sebesar $60,62 \%$ terhadap total pendapatan, meskipun saat ini hampir semua petani memiliki pekerjaan diluar usahatani sebagai pekerjaan sampingan. Tingkat pendapatan petani dari sumber pendapatan utama apalagi ditambah pendapatan sampingan jauh lebih besar dari UMK yang mengindikasikan bahwa petani sudah sejahtera namun distribusi pendapatan diantara petani masih sangat timpang.

2. Tingkat kesejahteraan petani tanaman pangan dan hortikultura di kecamatan Muara Sabak Timur dipengaruhi secara signifikan oleh tingkat pendapatan dan jumlah anggota keluarga dengan arah yang positif sedangkan pendidikan kepala rumah tangga berpengaruh signifikan dengan arah yang negatif.

3. Kesejahteraan petani tanaman pangan dan hortikultura di kecamatan Muara Sabak Timur perlu ditingkatkan lagi terutama dari sisi distribusi pendapatan dengan cara memperluas lahan serta mengoptimalkan usahataninya serta perlu peran pemerintah daerah untuk mendukung efisiensi dan efektifitas usaha tani.

\section{Daftar Pustaka}

Adriani, E., Hasminidiarty, H., \& Fahmi, A. (2020). Nilai Tukar Petani Dan Pola Konsumsi Rumah Tangga (Studi Kasus: Petani Tanaman Pangan Dan Hortikultura Di Kecamatan Sabak Timur Kabupaten Tanjung Jabung Timur). J-MAS (Jurnal Manajemen Dan Sains), 5(1), 77. Https://doi.Org/10.33087/Jmas.V5i1.152 Agresti, Alan. (2007). An Introduction to Categorical Data Analysis. Second Edition. John Wiley Sons. Inc. BPS Provinsi Jambi. (2020). Provinsi Jambi Dalam Angka 2020. Badan Pusat Statistik Provinsi Jambi.

Bungin, H.B. (2013). Metodologi Penelitian Sosial dan Ekonomi (1st Ed.). Kencana Prenada Media Group.

Burhansyah, R., \& Pribadi, Y. (2016). Analisis Indikator Kesejahteraan Petani Sayuran di Kota Pontianak. Prosiding Seminar Nasional Inovasi Teknologi Pertanian Banjarbaru, 20 Juli 2016,1634-1644. 
Evi Adriani, Susilawati dan Ali Fahmi, Struktur Pendapatan Rumah Tangga dan Tingkat Kesejahteraan Petani di Kecamatan Muara Sabak Timur Kabupaten Tanjung Jabung Timur

Http://Kalsel.Litbang.Pertanian.Go.Id/Ind/Images/Pdf/Semnas2016/202_Rusli_Burhansyah.pdf

Canita, P. L., Haryono, D., \& Kasymir, E. (2017). Analisis Pendapatan Dan Tingkat Kesejahteraan Rumah Tangga Petani Pisang Di Kecamatan Padang Cermin Kabupaten Pesawaran (5(3), 235-241.

Elizabeth, R., \& Darwis, V. (2000). Peran Nilai Tukar Petani Dan Nilai Tukar Komoditas Dalam Upaya Peningkatan Kesejahteraan Petani Kedelai (Studi Kasus: Propinsi Jawa Timur). Jurnal Ekonomi dan Kebijakan Pertanian, 28(2), 1-12.

Karolina, A., Bakce, D., \& Jum'atri Yusri. (2016). Analisis Pendapatan Dan Pola Konsumsi Rumahtangga Petani Kelapa Di Kecamatan Mandah Kabupaten Indragiri Hilir. JOM Faperta Vol.3 No. 1 Februari 2016, 3(1).

Keumala, C. M., \& Zainuddin, Z. (2018). Indikator Kesejahteraan Petani Melalui Nilai Tukar Petani ( NTP ) Dan Pembiayaan Syariah Sebagai Solusi. Economica: Jurnal Ekonomi Islam, 9(1), 129-149.

Mayasari, D., Satria, D., \& Noor, I. (2018). Analisis Pola Konsumsi Pangan Berdasarkan Status IPM Di Jawa Timur. Jurnal Ekonomi Dan Pembangunan Indonesia, 18(Januari), 191-213.

Nirmala, A., Hanani, N., \& Muhaimin, A. (2016). Analisis Faktor Faktor Yang Mempengaruhi Nilai Tukar Petani Tanaman Pangan Di Kabupaten Jombang. Habitat, 27(2). Https://Doi.Org/10.21776/Ub.Habitat.2016.027.2.8

Nurasa, T. dan Rachmat, M. (2013). Nilai tukar petani padi sentra produksi padi di Indonesia. Jurnal Agro Ekonomi, 31(2), 161-179.

Puspita, C. D., \& Agustina, N. (2020). Pola Konsumsi, Elastisitas Pendapatan, Serta Variabel-Variabel Sosial Ekonomi Yang Memengaruhi Pengeluaran Konsumsi Rumah Tangga. Seminar Nasional Official Statistics, 2019(1). Https://Doi.Org/10.34123/Semnasoffstat.V2019i1.46

Rahmadin, H. D., \& P, N. H. (2018). Analisis Nilai Tukar Petani Penggarap Di Kecamatan Gedeg Kabupaten Mojokerto. Swara Bhumi, V(6), 243-252.

Riyadh, M. I. (2016). Analisis Nilai Tukar Petani Komoditas Tanaman Pangan Di Sumatera Utara. JIM EKP FEB UNSYIAH, 53(9), 1689-1699. http://JIM.Unsyiah.ac.id/EKP/Article/View/689 